Revista Iberoamericana. Vol. LXVI, Núm. 191, Abril-Junio 2000, 367-379

\title{
INMIGRACIÓN, NACIONALISMO CULTURAL, CAMPO INTELECTUAL: EL PROYECTO CREADOR DE ALBERTO GERCHUNOFF
}

POR

Fernando Degiovanni

University of Maryland

El final de la Autobiografía (1914) de Alberto Gerchunoff (1883-1950) constituye uno de los puntos de partida más significativos a través de los cuales es posible analizar la temática de lo judío-argentino en el marco de su producción textual. El autor de Los gauchos judíos (1910) se sitúa allí frente al campo cultural de la Argentina del Centenario por medio de una serie de operaciones ideológicas que plantean una opción no sólo intelectual sino también específicamente literaria en la construcción de su proyecto creador. La afirmación: "Yo no aspiro a cantar únicamente la vida judía: soy ante todo argentino y mi carácter de tal orienta mi existencia de hombre de letras” (36) pone en evidencia la oposición temprana de Gerchunoff a cualquier intento de encasillamiento de sí mismo y de su obra dentro de una corriente costumbrista ligada a los estrechos límites de la comunidad inmigrante.

Si se investiga el contexto en el que Gerchunoff escribe esta frase no es difícil concluir que la deliberada apuesta por una nacionalidad “ajena” u “otra” en términos identitarios ("soy ante todo argentino") y por el libre ejercicio de una profesión dentro de ella (“existencia de hombre de letras”) se halla ligada a la necesidad de asegurar una posición central en la primera plana intelectual del país. Frases tan elocuentes como las aplicadas a la descripción de su niñez en la provincia de Entre Ríos — “En aquella naturaleza incomparable, bajo aquel cielo único, en el vasto sosiego de la campiña surcada de ríos, mi existencia se ungió de fervor, que borró mis orígenes y me hizo argentino” (26, énfasis mío); “Muy pronto aprendí las estrofas del Himno Argentino...” (27, énfasis mío) y “Mi pena era no ser como los demás, es decir, no ser argentino” (31, énfasis mío)—, resultan claras manifestaciones asimilacionistas de un inmigrante que, ya por entonces celebrado autor de Los gauchos judíos y periodista de La Nación, manifestaba en este texto su adhesión incondicional a los grupos de poder que le habían permitido formar parte de su núcleo intelectual y cultural.

El salto cualitativo que lleva a Gerchunoff desde una infancia cercana a la indigencia en las colonias inmigrantes de Entre Ríos, fundadas por el Barón Maurice de Hirsch, hasta su exitosa juventud porteña, debe leerse en relación a una serie de condiciones de movilidad social originadas en el fuerte impulso modernizador que afectaba a la sociedad argentina desde 1880. Es sabido que una modificación profunda de las relaciones económicas establecidas por la política de la burguesía liberal define, desde ese momento, otra situación del país dentro del concierto internacional del capitalismo económico. Las consecuencias 
de la definitiva madurez del orden neocolonial surgido hacia 1850 con la implementación de una política de la tierra destinada a la producción de materias primas para los centros europeos se hacen inmediatamente visibles en el plano social y cultural. La inmigración actúa aquí como el dato más ostensible en la redefinición de la realidad argentina; en efecto: como han puntualizado Beatriz Sarlo y Carlos Altamirano, el fomento de la llegada de extranjeros al país:

Traducía el programa concebido ya por los hombres de la organización nacional, que incluía la inmigración como medio no sólo de poblar el desierto, sino también de borrar los hábitos que se identificaban con el caudillismo y la barbarie rural. Se trataba de crear “desde arriba” la sociedad civil que debería convertirse en el soporte de un Estado nacional moderno de tipo capitalista (76).

La biografía de Alberto Gerchunoff debe entenderse en el marco de este proceso modernizador que desde 1880 tiene curso en el Río de la Plata. Nacido en Proskuroff, Lituania, en 1890 llega a América en compañía de su familia. Los inmigrantes se establecen en Moisés Ville, Santa Fe, primera de las colonias fundadas por el Barón de Hirsch. Luego del asesinato del padre a manos de un hombre de campo borracho, los Gerchunoff se trasladan a la colonia de Rajil, en la provincia de Entre Ríos, donde se convierten en agricultores "en el sentido total de la palabra” (Autobiografía 28). Ante los temores constantes de la madre, en 1895 pasan a Buenos Aires. Allí Gerchunoff es panadero, mecánico, cigarrero, pasamanero. Estudia de noche y da exámenes en condición de libre. Impulsado por su vocación literaria, al comenzar el siglo empieza a frecuentar las redacciones periodísticas. Trabaja en el interior del país. Llega a ser director de El Censor de Rosario y de allí logra dar un salto nuevamente a Buenos Aires, pasando de El País a La Nación, espacio de definitiva consagración intelectual por entonces.

En estas circunstancias, el primer factor que posibilita a Gerchunoff recorrer el extenso camino que separa al agricultor entrerriano del periodista porteño es la democratización de la vida social. Como el crecimiento del público urbano desborda la capacidad de los sectores tradicionales para atender las demandas del emergente circuito de transmisión de la información, es necesario apelar a nuevos sectores para cubrir estos puestos de trabajo; es entonces cuando por primera vez se establecen nuevas formas de iniciación cultural y los hijos de inmigrantes alcanzan un lugar en los círculos intelectuales.

El segundo factor que permite entender este ascenso, es un posicionamiento estratégico por parte de Gerchunoff en torno a la problemática que atraviesa el campo cultural del Centenario. Enfrentado al rechazo que la clase dirigente, manifiesta ante la presencia de extranjeros en el país, el autor-inmigrante buscará situarse en una posición coherente que le permita no ser excluido de su círculo de acción y, a la vez, no obliterar su identidad judía. Es así como los referentes intelectuales de la tierra de su infancia —la provincia de Entre Ríos-, y los valores políticos y culturales asociados a ella —el liberalismo de inspiración urquicista—, serán los materiales sobre los que se construirá esta doble estrategia.

Como queda señalado, el ingreso de Gerchunoff al ámbito de las letras se produce en uno de los momentos más álgidos del debate dirigente sobre el problema del extranjero en el país. La presencia inmigrante había despertado, hacia 1900, una fuerte disputa ideológica 
en torno al lugar de los nuevos sectores sociales en el contexto nacional. Promocionada por una política que las propias clases dominantes habían emprendido un cuarto de siglo atrás, la inmigración se convierte ahora en signo y portadora de otra barbarie. Como ha señalado Julio Ramos, estamos en presencia de "la paranoia de una clase que en su mismo proyecto modernizador — de erradicar la "barbarie” campesina — había generado nuevas contradicciones, que ya a fin de siglo relativizan su hegemonía” (Desencuentros 134). La dimensión cuantitativa de la inmigración y el consecuente surgimiento de conflictos obreros derivados de una incipiente lucha de clases comenzó a generar una fuerte aprensión por parte de los “criollos viejos". En estas circunstancias, la pregunta por la nacionalidad deriva de inmediato hacia el cuestionamiento por el nacionalismo cultural. Desde ese momento, el tema se convierte en el eje de la problemática estético-ideológica que atravesará el emergente campo intelectual argentino de comienzos de siglo.

El rechazo del extranjero es, en definitiva, el último de los escollos que el Gerchunoff inmigrante judío-ruso deberá sortear en su lucha por la legitimidad. El "mito de la raza” surge aquí como una de las estrategias más importantes con que los sectores tradicionales del poder responden a la nueva política de masas. El catolicismo, las filosofías espiritualistas, Nietszche y, de modo muy contundente, el hispanismo sirven como soportes del nuevo horizonte ideológico. Esto hace patente que las operaciones que Alberto Gerchunoff debía llevar a cabo para posicionarse como figura destacada en el campo intelectual eran complejas y difíciles. Su condición de inmigrante era el primer obstáculo que debía superar, pero éste, con todo, no era el más delicado. A su condición de inmigrante debía sumar su condición de judío. Dentro de una sociedad católica, los italianos se encontraban, en este sentido, en una situación más favorable. Gerchunoff, en cambio, debía luchar desde una diferencia doble.

El texto de Los gauchos judíos permite observar cómo Gerchunoff piensa a partir de 1910 los núcleos temáticos sobre los que operará su proyecto creador. Desde la nota final que señala: “este libro acabóse de imprimir en La Plata en los talleres gráficos de J. Sesé, el día X de mayo de MCMX”, es decir, apenas quince días antes de la celebración principal del Centenario de la Revolución de Mayo, hasta el anuncio de la segunda página que promete la escritura de otras dos obras tituladas Tierra de Sión y Los conversos, es notorio que el inmigrante judío utiliza en este período de su biografía literaria todas las estrategias a su disposición para formar parte del núcleo intelectual dirigente del país. A causa de este y otros hechos, la crítica —Germán García (1957), David Viñas (1964), Gladys Onega (1965), Saúl Sosnowski (1978), Edna Aizenberg (1987) y Naomi Lindstrom (1989)—, ha coincidido en afirmar que el proyecto creador de Gerchunoff estuvo completamente vinculado desde sus comienzos a la afirmación de una Argentina liberal en la cual su producción intelectual como judío-argentino pudiera desarrollarse sin "mayores incomodidades".

Los gauchos judíos puede ser considerado así como otro de los textos claves dentro del conjunto de los publicados con motivo del Centenario, entre otros, por Ricardo Rojas, Manuel Gálvez y Leopoldo Lugones. Una salvedad, claro está, se impone en este caso: Gerchunoff no podía trabajar, como harían los otros, a partir de la evocación nostálgica de un pasado que los efectos de la modernización y su consecuencia más importante, la inmigración, estaban desintegrando. Su circunstancia personal estaba lejos de ser la de un 
hidalgo de provincia afectado por la "vulgarización” de la sociedad. Aunque tres años después recuperará su deuda con el hispanismo a través de Nuestro Señor Don Quijote (1913), en 1910 el inmigrante judío opta, en cambio, por una solución al mismo tiempo adecuada al horizonte ideológico liberal de los círculos dirigentes del país a los que ya se había acercado y conforme a su biografía personal; adapta, desde su perspectiva, uno de los nuevos ideologemas de legitimación forjados por los patricios modernizadores como respuesta al tráfago urbano, mercantilista: el de la exaltación del interior del país como espacio que conserva el ideal tradicional del "alma nacional”. En el escenario de la provincia de Entre Ríos describe a sus paisanos rusos como "gauchos”, idealizando así no sólo el campo como región incontaminada, sino también resaltando su laboriosa acción como agentes del desarrollo económico nacional.

Si bien Gerchunoff nunca llegó a escribir los textos que se anunciaban al comienzo de Los gauchos judíos, puede afirmarse que los núcleos estético-ideológicos que parecían despuntar en ellos permanecerán como constantes en el resto de su obra. No es arriesgado afirmar, en este sentido, que el proyecto de Tierra de Sión encontrará su forma definitiva en Entre Ríos, mi país (1950) y que Los conversos, por su parte, será el prototexto de Enrique Heine, el poeta de nuestra intimidad (1927) y Los amores de Baruj Spinoza (1932), novelas sobre conversos.

En La identidad judía en la literatura argentina, Leonardo Senkman puntualizó una de las estrategias más notables que Gerchunoff utiliza "para ostentar una identidad que buscaba legitimarse y ser legitimada” (201). El crítico ha señalado que aún a pesar de los artículos escritos por Gerchunoff en la etapa de recudrecimiento del fascismo y el nazismo en los años 30 y 40, su inalterable filocristianismo e hispanismo literario, acordes al horizonte ideológico de su época, son el índice más claro de una impertérrita adhesión al ideario de la república liberal (200). Asimismo, con el propósito de destacar otros movimientos estratégicos que Gerchunoff realizó como signo de su adhesión a las figuras más destacadas del campo cultural argentino, recuerda tanto los notorios silencios que el autor mantuvo hacia algunos de los hechos decisivos que, en su momento, comprometieron dramáticamente la situación de los judíos en la Argentina, ${ }^{1}$ como sus constantes retornos a La Nación, su "hogar" intelectual.

El texto de Senkman prueba cómo a través de la tradición que recupera de Europa la lengua de Cervantes y la conversión religiosa de Enrique Heine y Baruj de Spinoza, Gerchunoff procesó los temas ideológicos que atravesaban el debate intelectual del Centenario para “presentar sus respetables credenciales ante los Ricardo Rojas y los Roberto

\footnotetext{
${ }^{1}$ Entre los más destacados se cuenta su ausencia de declaraciones acerca del pogrom que se abatió en la "Semana Trágica" de enero de 1919 sobre el barrio judío del Once [Gerchunoff no se encuentra entre quienes respondieron a la encuesta que la revista Vida nuestra realizó a propósito de estos hechos en su número 7; tampoco hizo manifestación alguna en sus Cuentos de ayer y en el prólogo a Los cabalistas de I. L. Peretz, todos de 1919 (Senkman 202-204)]. Asimismo no intervino públicamente frente a la fuerte lucha antisemita desatada en 1932 por la Liga Patriótica a través del diario Bandera Argentina y por la Comisión Popular Anticomunista en el mitín convocado en la Plaza del Congreso [ante estos hechos reaccionaron, en cambio, sus amigos Sanuel Eichelbaum, Enrique Dickman y Alejandro Portnoy; por su parte, Jorge Luis Borges, Ricardo Rojas y Luis Emilio Soto participaron en el desagravio (Senkman 216)].
} 
Payró” (213), ante Leopoldo Lugones, su “patrono literario” (211), y Manuel Gálvez —los "herederos y amanuenses ideológicos" de los "gentlemen intelectuales del 80" (213). Sin embargo, una descripción exhaustiva de los referentes culturales en relación a los cuales se define el proyecto creador de Gerchunoff evidencia de inmediato que su liberalismo político encuentra no sólo fundamento en una tradición europea sino que el autor se valió de otra, local, que opera a la vez como término opuesto y complementario de la primera. Senkman omite en su análisis este otro segmento de ese recorrido textual, a la vez tan importante y eficaz como el europeo en la serie de construcciones "míticas" con las que el liberalismo respondió al debate del momento: es el que tiene que ver con lo telúrico "provincial” y remite a los nombres de Martiniano Leguizamón, el prologuista de la primera edición de Los gauchos judíos, y Olegario V. Andrade, el poeta civil de la Generación del 80.

Al igual que lo que ocurre con el sector europeo, se trata aquí del estudio del otro lado de un proyecto construido sobre referentes intelectuales para reafirmar simbólicamente su fidelidad a un modelo de nación al que los judíos pudieran integrarse. En efecto: estas figuras sirven para apuntalar aspectos diferentes de su lucha en favor del liberalismo. Admiradores profundos de Justo José de Urquiza, el vencedor de Rosas en la batalla de Caseros (1852), Leguizamón, por un lado, está ligado al proyecto creador de Gerchunoff por cuestiones principalmente "sociológicas" - ya que permite describir las estrategias del autor relacionadas con su lucha por el ingreso al campo cultural del Centenario a través de Los gauchos judíos; Andrade, en cambio, aparece al final de la vida del autor vinculado a una dimensión específicamente "simbólica" — en la medida que constituye el emblema con que Entre Ríos, mi país responde a episodios políticos de la década de 1940. Se trata, en definitiva, de la construcción de una paternidad textual en cuyo seno se enconde un fuerte deseo de filiación en el que se cruzan lo político-ideológico y lo estético-literario; deseo de filiación que articula una identidad cultural a través de un proyecto creador.

Martiniano Leguizamón (1858-1935) aparece como el primer referente intelectual en la obra de Alberto Gerchunoff: el escritor actuó como presentador de Los gauchos judíos ante el público argentino. Su carácter de autor del prólogo del texto da las pautas acerca de la opción estético-ideológica que Gerchunoff realizó al comienzo de su itinerario intelectual, al tiempo que permite observar con claridad sus estrategias de posicionamiento en el campo cultural.

Unos pocos datos biográficos y escriturarios sirven para trazar líneas de continuidad entre uno y otro autor. De origen entrerriano; dramaturgo, cuentista e investigador del folklore y las tradiciones gauchas argentinas, Leguizamón era en el momento de la publicación de Los gauchos judíos, no sólo una personalidad importante ligada a los círculos de poder sino una figura notoria de la literatura nacional. Durante las presidencias de Julio A. Roca (1880-1886) y Miguel Juárez Celman (1886-1890) se había desempeñado como director del Boletín Oficial de la Nación y abogado del Banco Hipotecario Nacional. Desde el punto de vista específicamente literario era por entonces el autor del afamado drama Calandria (1896) y del romance histórico Montaraz (1900), centrados en la evocación costumbista del gaucho entrerriano. Sumado a esto, trabajaba como colaborador en los dos espacios de legitimación cultural más sólidos de la Argentina del 900: el diario La Nación y la revista Caras y Caretas. 
Precisamente es en las redacciones de estos medios periodísticos donde debe buscarse el punto de intersección biográfica entre ambos autores. En efecto: Gerchunoff, que colaboraba en Caras y Caretas desde 1900 e ingresó a La Nación en 1908 de la mano de Roberto J. Payró, encontró en Leguizamón al escritor consagrado que llenaba los requisitos necesarios para disponer favorablemente su obra en la red intelectual del Centenario. Compartía con él una postura política —el liberalismo del 80-, un “origen” —era entrerriano de nacimiento- - y una temática común — los "gauchos" de las "cuchillas" de Montiel. El "Prólogo" de Los gauchos judíos remarca desde el comienzo estas líneas de cruce y explicita la posición privilegiada desde la que habla el "padre":

Regresaba del campo después de haber respirado a pulmón pleno el aire tranquilo de las tardes, saturado de pampa y con la imagen en la retina de esas admirables puestas de sol que tiñen con colores de fuego la verde curva de las lomas, cuando vino a reavivar mis férvidos cariños natales, la lectura de sus páginas frescas, henchidas de aromas y sabor argentino.

Decir que las he leído con verdadero deleite, conociendo mi inalterada simpatía hacia las obras que hunden su raigambre en el sentimiento de las cosas nuestras, es casi una redundancia (ix).

De aquí en adelante, la presentación de Leguizamón jugará entre los perversos límites que separan la alabanza de la prescripción. A la vez que llama a Gerchunoff “artista” (x) y señala "las excelencias de una (sic) alma de poeta que sabe sentir y pintar la naturaleza nuestra” (xv), destaca extensamente al "joven escritor" que "con tan justos títulos se incorpora al raleado grupo de los escritores nacionales, dando así un saludable ejemplo a los nativos que por temor o pereza desdeñan los asuntos de la tierra esterilisándose (sic) en imitaciones exóticas sin sentimiento ni originalidad" (xiii).

Este fragmento resume, en realidad, todo un programa literario. Si por un lado apunta el rechazo de una estética ligada a lo extranjerizante-estetizante —léase modernismo — por otro señala los rasgos del círculo intelectual al que ingresará el advenedizo. Leguizamón indica, en realidad, los límites de una estética cuya adopción significa una postura política definida en el nuevo contexto nacional. En relación a Gerchunoff puntualiza, en este sentido, "el alto sentimiento de gratitud y amor hacia la tierra generosa" que une estas "páginas inconexas" (x) para terminar recalcando que el autor de Los gauchos judíos “comprueba con esta obra de arte y verdad un cariño acendrado por la tierra de adopción” (xv). El énfasis de Leguizamón era comprensible: había en la obra de Gerchunoff una representación original de la situación del gaucho que el prologuista ya había propuesto en Calandria con el objetivo de redefinir simbólicamente su lugar social y económico en la organización rural.

Calandria presenta por primera vez en la historia del teatro argentino la imagen del gaucho domesticado como criollo trabajador, alejado de ese estereotipo de sujeto alzado y pendenciero que contribuyó a difundir principalmente Juan Moreira (folletín 1879-1880; pantomima 1884; versión dialogada de Podestá 1886). Calandria, desertor que vive esquivando y desafiando a la policía por altivez y amor a la libertad, es finalmente recobrado por la sociedad: logra el indulto de las autoridades y, a partir de esa nueva situación, acepta 
mudar su condición de matrero por la de puestero. En la décima parte del drama, titulada sugerentemente “Redención”, el personaje, en vísperas de su casamiento con Lucía, la “flor del pago”, exclama:

\author{
Ya este pájaro murió \\ En la jaula de estos brasos [sic] (A Lucía) \\ Pero ha nasido [sic], amigasos, \\ El criollo trabajador! (107).
}

Osvaldo Pellettieri ha demostrado cómo el "nativismo" de Calandria constituye una respuesta estética al orden liberal emergente: el texto se puede leer como el lema "paz y administración” del roquismo llevado al teatro (253). La imagen de los colonos judíos que Gerchunoff presenta en la obra se acomoda perfectamente a la necesidad reformadora de Leguizamón: son a la vez agricultores y “gauchos”, esto es, como señaló Jorge L. Borges, "chacareros”. ${ }^{2}$ La afirmación: “esta página de la vida provinciana ... servirá al psicólogo del futuro para estudiar las fases más curiosas de la transformación del tipo [gaucho] originario" (xiii) muestra explícitamente el modo en el que Leguizamón leía la obra de su protegido dentro del nacionalismo del Centenario. Para Leguizamón, el texto de Gerchunoff constituía un agente simbólico efectivo para la consolidación de ese proyecto liberal que, ansioso por disolver lo "otro", necesitaba domesticar al gaucho y asimilar al judío a la nueva política de la tierra:

La obra será lenta, sin duda, pero concluirá al fin su evolución inevitable cuando los ancianos judíos desaparezcan y sobre el solar poblado de bíblicas añoranzas, los hijos de sus hijos, argentinos por la fusión de la sangre, encariñados a la tierra que les entrega sus riquezas ubérrimas, libre de preocupaciones y de recelos, con la alegría y la paz del hogar risueño que les colma de dicha el corazón, entonen en las fiestas de la nueva centuria el cántico glorioso de la libertad argentina (xii-xiii, énfasis mío).

En este contexto, tras haber evaluado el libro, Leguizamón pronuncia ceremoniosamente el veredicto aprobatorio: "podemos saludarle como a uno de los escritores de la tierra" (xv) y, como si eso no bastara, remata su sentencia adoctrinando: "He ahí la rica cantera que debe explotar con espíritu exento de preocupaciones de raza, sin amoldarse a los cánones de ninguna secta literaria dejando que la pluma tome el ritmo natural y las imágenes encuentren su camino” (xv-xvi, énfasis mío).

En 1935, es decir, veinticinco años después de la publicación de Los gauchos judíos, Gerchunoff todavía mantendrá su deuda de gratitud hacia Leguizamón. En la nota aparecida en La Nación con motivo de su muerte, destacará nuevamente en él los valores que lo

\footnotetext{
${ }^{2}$ Con su sagacidad habitual, Borges fue quizás el primero en notar los móviles que Gerchunoff persiguió con la publicación de esta obra. En su comentario de Los gauchos judíos remarca: "ese libro de Gerchunoff ... tiene un título que no corresponde al texto. Porque, cuando uno lee el libro, se da cuenta de que esos inmigrantes judíos no eran gauchos sino chacareros. Y eso se ve en los mismos capítulos, que se titulan "El surco", "La trilla”, etcétera. Eso no tiene nada que ver con un gaucho, que fue un hombre ecuestre, y no un agricultor”. Jorge L. Borges, Siete conversaciones con Jorge Luis Borges, por Fernando Sorrentino (36, énfasis mío).
} 
llevaron a elegirlo como prologuista: “un temperamento de artista, impregnado de tradición, con sabor y olor a tierra natal, en quien la potencia plástica y la profusión generosa tenían la virtud de atraer y de conquistar" (Figuras de nuestro tiempo 220), un hombre en que se podía descubrir "las condiciones proverbiales del criollo antiguo, y en quien tuvo el criollismo un representante ilustre, un reconstructor y un maestro" (222). La afirmación con que concluye la nota: “tiene su obra la trascendencia de un tributo patriótico” (222), explicita una vez más su fidelidad y reconocimiento a la figura del precursor y confirma, a la distancia, el compromiso inalterable hacia la Argentina como su Sión.

Al lado de Leguizamón, es posible verificar entre los precursores de Gerchunoff a otro escritor ligado directamente al programa de la Generación del 80: Olegario V. Andrade (1841-1882). Andrade es el último de los referentes intelectuales argentinos en la obra de Gerchunoff y, como en el caso del autor de Calandria, un repaso por su biografía literaria pone al descubierto las afinidades electivas que justifican esta filiación en términos políticos y estéticos. Otra vez vuelven a hacerse patentes aquí ese núcleo de ideologemas en función de los cuales Gerchunoff construyó su tradición intelectual en las letras argentinas: una misma pertenencia territorial —la provincia de Entre Ríos - y una misma matriz liberal aplicada al tratamiento de los temas patrios.

Andrade estuvo ligado desde su adolescencia a los prominentes nombres de Julio A. Roca y Eduardo Wilde, de quienes fue condiscípulo en el Colegio de Concepción del Uruguay. A pesar de su inicial oposición periodística al centralismo porteño, su lucha cesa cuando se establece en Buenos Aires durante la presidencia de Nicolás Avellaneda (19741880). Nombrado diputado en representación de Partido Autonomista Nacional, inicia su etapa celebratoria del ideario porteño. En este sentido, Ricardo Rojas ha señalado que:

Las aficiones literarias del presidente y la influencia política de Roca, su ministro de guerra, ex condiscípulo y amigo del poeta, favorecieron su notoriedad porteña, de tal modo que, al producirse la federalización de Buenos Aires (1880), Andrade, ya laureado en varios certámenes, y autor ya de aplaudidos poemas, era considerado como el poeta nacional. Sus mejores cantos —El nido de cóndores, Prometeo, San Martín, Atlántidapertenecen a este período. Con estos cantos logró el aplauso de los selectos y alcanzó la popularidad (Historia de la literatura Argentina, vol. I, 281).

Rafael A. Arrieta escribió, por su parte, que "en aquellos cantos reconoció el país la gran voz lírica de su etapa adulta. La ya cumplida organización nacional había hallado su poeta” (Historia vol. III 307-308). La edición póstuma de sus Obras poéticas (1887) por parte del gobierno nacional y la oración fúnebre pronunciada ante sus restos por el presidente Julio A. Roca terminan consagrando a ese poeta que, en palabras de Rojas, "era una gloria cívica de su partido y una gloria civil de su país” (283).

Un análisis de Entre Ríos, mi país permite destacar la importancia que el autor de Los gauchos judíos otorga a la escritura de su “comprovinciano” en el ámbito de la literatura latinoamericana. El final del capítulo sobre Andrade ("La ciudad del poeta: Gualeguaychú”) señala las claves de su lectura: 
Las nubes le sugirieron [a Andrade] la evocación del Cáucaso y de Prometeo, el amor de la libertad, el sentimiento ardoroso y heroico de la justicia. Por haber sabido interpretar su mudo idioma, por haber sabido leer los signos indescifrables, lo llevamos en nuestro pensamiento y no podemos recordar la ciudad provinciana [Gualeguaychú] sin que a nuestras almas asome la gratitud, porque de allí surgió el poeta civil más grande y más fuerte de América Latina, el poeta de Prometeo, el poeta de Atlántida (126).

Según el propio Andrade, Prometeo (1877) es “un canto al espíritu humano, soberano del mundo, verdadero emancipador de las sociedades esclavas de tiranías y supersticiones” (71). Pero dentro de este marco, como puntualiza Guido y Spano, el texto repite la tesis de Quinet según la cual "Prometeo es el verdadero profeta de Cristo en el seno de la antigüedad griega” (9). En la parte V del poema, Andrade sintetiza esta idea. Presenta a Prometeo, de pie en la montaña, presenciando "Sobre la excelsa cúspide de un monte /.../ ¡en medio del espanto de los mundos,/ De una cruz la fantástica silueta!” (85):

“¡Al fin puedo morir!”, grita el gigante

Con sublime ademán y voz de trueno.

Aquélla es la bandera de combate,

[que] va a desplegar el pensamiento humano

Teñida con la sangre de otro mártir

-Prometeo cristiano-,

¡Para expulsar del orgulloso Olimpo

Las caducas deidades! (86).

El ideario cristiano de Prometeo se consolida y encuentra una dirección más específica en Atlántida (1881). Allí Andrade concede a la "raza latina” un destino mesiánico en la historia universal. Luego de esbozar un recorrido diacrónico por las civilizaciones occidentales protagonistas de la historia (Roma, Italia, España, Francia) sitúa a América Latina, y especialmente a la Argentina, como último bastión en la cadena de naciones poderosas y triunfantes. América Latina es, en la perspectiva de Andrade, la destinataria de una empresa histórica secular que Dios le reservaba desde la Antigua Grecia; a la Argentina, por su parte, corresponde la realización de las "grandiosas ilusiones/ La libertad, la gloria y el progreso" (66):

¡Pero Dios reservaba

La empresa ruda al genio renaciente

De la latina raza, domadora

De pueblos, combatiente

De las grandes batallas de la historia! (66).

¡La Patria!, en ella cabe

Cuanto de grande el pensamiento alcanza,

En ella el sol de redención se enciende,

¡Ella al encuentro del futuro avanza,

Y su mano, del Plata desbordante,

La inmensa copa a las naciones tiende! (69). 
Los últimos versos subrayan desde una perspectiva poética las pretensiones del proyecto liberal:

¡Aquí va a realizar lo que no pudo

Del mundo antiguo en los escombros yertos

La más bella visión de las visiones!

¡Al himno colosal de los desiertos

La eterna comunión de las naciones! (70).

Los poemas de Andrade desarrollan, así, una didáctica patriótica en la que inmigración y cristianismo deben combinarse para garantizar el éxito del destino de la república. Notoriamente, en su exaltación del liberalismo entrerriano, Gerchunoff prefirió no ver en Andrade al cantor de la "raza latina” y de las civilizaciones cristianas sino más bien al representante de "esa vocación de vida espiritual, hoy difundida en la populosa clase media” que encarna "en el país el idealismo cívico, con una concepción continental” (50), al "hombre urbano" que “encarna en la provincia los fáciles postulados del liberalismo, antidogmático, popularista, impregnado de los conceptos de amplitud humana” (45). Andrade fue, para el autor de Los gauchos judíos, el heredero del liberalismo de Mayo; a propósito señaló: "Procedía sentimentalmente de la generación fundadora de la nacionalidad” (50) y agregó: “Andrade resumió en su acento atronador los ecos últimos de la América fraternal, de la América de la Revolución, y asumió en su misión de poeta el albaceazgo de Mayo” (80). Su apoyo a la opción ideológica a la que este autor sirvió, aparece claramente remarcada en su juicio concluyente: "Fue el poeta de nuestra civilidad y de nuestra aspiración a la sociedad democrática” (52).

La apelación a Andrade, luego de casi cuarenta años de interrupción de una fidelidad provincial a la que en 1910 había sido tan afecto por motivos personales y estratégicos, no se debe atribuir ya, claro está, a una necesidad de reconocimiento; tampoco resiste una lectura desde los parámetros de un brote tardío de nostalgia. ¿Cuáles son, entonces, las motivaciones que soportan esta elección por parte de un intelectual judío-argentino tan pendiente de la cuestión nacional? Las respuestas parecen provenir del campo del poder. Si se repasa con atención el marco a partir del que Gerchunoff habla de Andrade en Entre Ríos, mi país no es difícil advertir que el texto es, explícitamente, un alegato en contra de la política de Perón y el peronismo del momento. Hacia 1950, su discurso tiene que ver, en consecuencia, con el emplazamiento de un artefacto simbólico capaz de desafiar el orden político contemporáneo.

Partiendo de la clásica oposición civilización-barbarie, Gerchunoff se pregunta por la significación de los políticos liberales argentinos y responde:

Representan la guerra al gaucho, esto es la lucha contra el individuo inavenible con la convivencia civilizada. Del año 53 data esa ardua batalla; Mitre, Sarmiento, López son los antigauchos, antimontoneros, que aspiran a fijar al país un régimen estable, dignificador y susceptible de perfectibilidad (48).

Gerchunoff fija en Rosas el antecedente nacional de lo que él llamó por esos días “la crisis de las ideas democráticas” (86) cuya manifestación más notoria es “el resurgimiento 
del nacionalismo agresivo, el retorno a los gobiernos personales” (86). El autor tenía presente, claro está, la situación internacional, pero sus cuestionamientos vuelven siempre a problemáticas locales: “¿Cuál sería la suerte del país, vista en la lejanía del tiempo, si reemplazáramos la democracia por los procedimientos que preconizan sus adversarios?” (86).

Si se recuerda que el gaucho de Gerchunoff es un “criollo trabajador”, un “chacarero”, debemos leer claramente desde el comienzo de su obra que el gaucho judío es, entre otras cosas, el gaucho del proyecto liberal; que su criollo trabajador es, asimismo, el reverso del bárbaro de Sarmiento: "después de las guerras de la libertad lo esencial consistía en el desgauchamiento, y en esa misión estaban los enemigos de Rosas, los que le sucedieron y dieron a la Nación coherencia durable, unidad de sentimiento, interna amalgama y uniformidad” (75). Admiradores de Urquiza, el vencedor de Rosas, Andrade y Leguizamón representan, en este contexto, los más firmes valores de ese liberalismo al modo entrerriano que él intentaba restaurar, de ese “Entre Ríos, [que] desde la reacción contra Rosas, se pone al servicio de la política de los hombres que definen la orientación europea, la política del consentimiento de los ciudadanos, de la sanción del pueblo, contra la política brutal y anárquica de la imposición, de la fuerza de mando...” (48).

A “esa crisis de las ideas de libertad y de democracia” (88) encarnadas en el nacionalismo fascista —prolongación histórica de la línea rosista— que Gerchunoff está viviendo con la política del peronismo, opone su esperanza al retorno de lo que él caracteriza como el "idealismo de la época creadora” (89), su utopía retrospectiva:

Volveremos, por lo tanto, al mesianismo de los obreros económicos y de los conformadores sociales de la Argentina de 1886 a 1930 ... Retornaremos al equilibrio democrático, a la mesura convivial, sin altibajos violentos, sin barbarie y sin regímenes extorsivos; al ritmo de antes, a las ínfulas mesiánicas de antes, al espejismo del servicio humano, sin el cual ni pueblos ni religiones fueron venas de la vida civilizada (89-90).

Hacia 1950, los objetivos de Andrade como intelectual de la Generación del 80 servían a Gerchunoff para oponer liberalismo institucionalista a fascismo antidemocrático. Así, en una época en que su discurso tenía principalmente como objetivo una tenaz militancia antinazi, los versos finales de la Atlántida que afirman: "Y su mano, del Plata desbordante/ La inmensa copa a las naciones tiende", y bregan por la "eterna comunión de las naciones", se reescriben en Entre Ríos, mi país a través del "yo" de un judío de origen ruso que, situándose desde la perspectiva de un hombre del 80, se disuelve en un “nosotros” argentino:

Nosotros, en la Argentina, nos inflamamos con la volición del progreso económico y le dimos, con la remembranza del idealismo revolucionario de 1810, con el romanticismo de la sociedad igualitaria, con el aventurerismo que impulsó la conquista y la colonización, la trascendencia de una empresa mesiánica, nos hicimos los misioneros de los que no tenían cabida en sus viejos lares. "Venid” —les dijimos—; aquí tendréis lo que os falta (85).

Y ya sin recordar acciones discriminatorias, olvidando pogroms y leyes de residencia, afirma: "Los aluviones internacionales arribaban a la Argentina sin que se temiese a lo que 
pudieran traer, a los problemas que podían provocar con su diversificación y con su tardanza en la adaptación al nuevo medio físico y social” (83).

Así, Andrade y Leguizamón aparecen en el árbol genealógico del autor de Los gauchos judíos como los referentes intelectuales de un proyecto creador que persiste en mantenerse ideológicamente fiel a sí mismo. A través de su posicionamiento como último eslabón de la cadena entrerriana, Gerchunoff buscó con insistencia construir un espacio político y cultural donde albergar su condición de escritor judío-argentino. Su estrategia era perfectamente consciente: ocupándose en La Nación del fallecimiento de Leguizamón, se refirió a este árbol genealógico provincial en el que cada uno es legitimado por su antecesor inmediato en función de una red de contenidos estético-ideológicos explícitos:

[Leguizamón] se sentía hombre de letras; en su espíritu influía el augurio con que le saludó su glorioso comprovinciano Olegario Andrade con motivo de su Canto a la bandera de los Andes. Desde entonces, puede decirse, fue esencialmente escritor, a pesar de que se consagró a funciones públicas, a la enseñanza, a su bufete de abogado (219).

Como Leguizamón encuentra en Andrade a su padre legitimador, Gerchunoff, a su vez, encontrará en Leguizamón ese “augurio" de su "glorioso comprovinciano" con motivo de Los gauchos judíos. Esta filiación tiene asimisimo, otros detalles para su justificación: en 1924, Leguizamón fue, además, como señala Arrieta, uno de los ordenadores y críticos de la vida y obra de Andrade, cuya divulgación había estado hasta entonces poblada de errores cronológicos (Historia vol. III 306).

El constante interés de Gerchunoff por la figura del intelectual, del "hombre de letras", no se agota, sin embargo, en estos nombres. Por el contrario, se observa repetidamente en su vida y en su producción escrituraria. Desde su temprana relación con Roberto J. Payró y los miembros del diario La Nación — cuya veneración puede reconocerse en los textos de Figuras de nuestro tiempo-, hasta su devoción por Cervantes, Heine y Spinoza, toda su biografía literaria puede leerse como una metafórica búsqueda de "padres" literarios capaces de legitimar su filiación-otra: su condición de judío dentro de una sociedad católica.

Leguizamón y Andrade constituyen, dentro de este conjunto, las dos condensaciones de esa inalterable fidelidad que Gerchunoff mantuvo frente al liberalismo argentino a través de un arco de casi 40 años de cambios políticos y sociales; en ellos están comprendidos y comprometidos alguno de los acontecimientos más decisivos para el destino judío en la historia mundial. Esa Autobiografía escrita a una edad en que habitualmente nadie escribe su autobiografía, no hace sino remarcar el énfasis con que el autor selló, a los treinta y un años de su edad, un compromiso definitivo con el ideario de la eufórica Argentina del Centenario. 
BibliografíA

Aizenberg, Edna. "Parricide on the Pampa: Deconstructing Gerchunoff and His Jewish Gauchos”. Folio 17 (1987): 24-39.

Altamirano, Carlos y Beatriz Sarlo. "La Argentina del Centenario: campo intelectual, vida literaria y temas ideológicos”. Ensayos argentinos: De Sarmiento a la vanguardia. Buenos Aires: Centro Editor de América Latina, 1983. 69-105.

Andrade, Olegario V. Obras poéticas. Buenos Aires: Sopena, 1938.

Arrieta, Rafael A. Historia de la literatura argentina. Buenos Aires: Peuser, 1959.

García, Germán. La novela argentina: Un itinerario. Buenos Aires: Sudamericana, 1952.

Gerchunoff, Alberto. Figuras de nuestro tiempo. Buenos Aires: Vernácula, 1979. Entre Ríos, mi país. Buenos Aires: Futuro, 1950.

Los gauchos judíos. La Plata: Joaquín Sesé, 1910.

Leguizamón, Martiniano. Calandria. Del tiempo viejo. Buenos Aires: Hachette, 1961.

Lindstrom, Naomi. Jewish Issues in Argentine Literature: From Gerchunoff to Szichman. Columbia: University of Missouri Press, 1989.

Onega, Gladys. La inmigración en la literatura argentina 1880-1910. Santa Fe: Universidad Nacional del Litoral, 1965.

Pellettieri, Osvaldo. "Calandria, de Martiniano Leguizamón, primer texto nativista”. Revista Canadiense de Estudios Hispánicos 15 (1991): 251-265.

Ramos, Julio. Desencuentros de la modernidad en América Latina: Literatura y política en el siglo XIX. México: Fondo de Cultura Económica, 1989.

Rojas, Ricardo. Historia de la literatura argentina: Los modernos. Buenos Aires: Losada, 1948.

Senkman, Leonardo. La identidad judía en la literatura argentina. Buenos Aires: Pardés, 1983.

Sosnowski, Saúl. “Contemporary Jewish-Argentine Writers: Tradition and Politics”. Latin American Literary Review 12 (1978): 1-4.

Viñas, David. Literatura argentina y realidad política. Buenos Aires: Jorge Álvarez, 1964. 